\title{
Tożsamość narodowa polskich studentów przebywających za granicą $^{2}$
}

Autorka podejmuje próbę odpowiedzi na pytanie, w jaki sposób tożsamość narodowa jednostki jest modyfikowana w sytuacji migracji. Badania własne zostały przeprowadzone wśród polskich studentów, którzy przebywają za granicą w celu odbycia studiów. Dla celów operacyjnych autorka przyjęła, że tożsamość narodowa to zbiór autodefinicji jednostki, odnoszących się do dwóch elementów, a mianowicie: do identyfikacji narodowej oraz do walencji kulturowej. Na podstawie analizy przypadków zostało wyróżnionych pięć typów modyfikacji tożsamości tj.: „ja” Polak - obywatel świata; „ja” obywatel świata, urodzony w Polsce; „ja” Polak, obywatel obecnego kraju pobytu i obywatel świata; „ja” Polak i obywatel obecnego kraju pobytu; „ja” obywatel świata i/lub obywatel obecnego kraju pobytu.

Słowa kluczowe: tożsamość, identyfikacja narodowa, walencja kulturowa, migracja, polscy studenci

\section{National Identity of Polish Students Living Abroad}

Abstract: The author attempts to answer the question of how the national identity of individuals is modified by migration. The fieldwork was conducted among Polish students who were living abroad to study at university. The author assumed, for the purposes of the research, that national identity is the self-definition that refers to national identification and cultural valence. Based on case studies analyses, five types of modified identities were distinguished: "I" Polish - a citizen of the world; "I" a citizen of the world born in Poland; "I" Polish, a citizen

${ }^{1}$ Kontakt: luczak.marta@wp.pl

2 Artykuł został opracowany na podstawie niepublikowanej rozprawy doktorskiej pt. „Modyfikacja tożsamości narodowej polskich studentów studiujących za granicą", napisanej pod kierunkiem prof. dra hab. Andrzeja Szpocińskiego, Collegium Civitas, Warszawa 2016. 
of the country of residence and a citizen of the world; "I" Polish and a citizen of the country of residence; "I" a citizen of the world and/or a citizen of the country of residence.

Keywords: identity, national identification, cultural valence, migration, Polish students

\section{Tożsamość - proces czy stan?}

W praktyce społecznej pojęcie „tożsamość” łączy się z fundamentalnym dla człowieka pytaniem o to, „kim jestem?”. Jednostka zadaje je sobie na przykład w momencie odmiany sytuacji życiowej, przyjęcia nowej roli społecznej, zmiany otoczenia społecznego, nawiązania relacji z nowymi osobami. Brak jednoznacznej i klarownej definicji może stać się źródłem niepokoju i skłonić do poszukiwania odpowiedzi.

W świecie nauki pojęcie „tożsamość” jest ujmowane jako świadomość praktyk oraz zbiór wyobrażeń, sądów i przekonań aktora społecznego (indywidualnego lub grupowego) o sobie samym ${ }^{3}$. Wskazana definicja jest jedną spośród licznie opracowanych w socjologii oraz w innych dyscyplinach naukowych. Szerokie zainteresowanie tematyką tożsamości wynika przede wszystkim z niejasności tego pojęcia, które łączy w sobie cechy, na pozór, sprzeczne $e^{4}$. Problem, przed którym stoją badacze, dotyczy na przykład tego, czy „tożsamość” należy postrzegać jako trwałą strukturę, stabilny konstrukt, spójną wewnętrznie całość (kryterium stanu, por. Erikson ${ }^{5}$ ) czy raczej jako ciągły proces, warunkowany przez interakcje społeczne, w trakcie którego tożsamość ulega zmianom (kryterium procesu, por. Mead ${ }^{6}$ ).

Próbując rozwikłać ten problem, wskazuje się na dwie cechy tożsamości: poczucie ciągłości i identyczność. Ciągłość jest wyrażana poprzez odwoływanie się jednostki do własnych, dla niej unikalnych, doświadczeń z przeszłości. Identyczność $z$ kolei pozwala jednostce na poczucie bycia jedną i tą samą osobą, pomimo zmian związanych z wiekiem i z wydarzeniami, które przynosi życie ${ }^{7}$. Tożsamość pozwala mieć poczucie bycia tą samą osobą (uważać się za tę samą osobę), a jednocześnie umożliwia dostosowanie się do zmian zachodzących w wyobrażeniach o sobie pod wpływem nowych doświadczeń i sytuacji życiowych

3 Z. Bokszański (2002), Tożsamość, w: Bokszański Z. et al. (red.), Encyklopedia socjologii, tom 4, Warszawa: Oficyna Naukowa, s. 252.

${ }^{4}$ Z. Bokszański (2005), Tożsamości zbiorowe, Warszawa: Wydawnictwo Naukowe PWN, s. 33-34.

${ }^{5}$ E. H. Erikson (2004), Tożsamość a cykl życia, Poznań: Zysk i S-ka. Naukowe.

${ }^{6}$ G. H. Mead (1975), Umysł, osobowość i społeczeństwo, Warszawa: Państwowe Wydawnictwo

${ }^{7}$ H. Malewska-Peyre (1992), Ja wśród swoich i obcych, w: Boski P., Jarymowicz M., Malewska-Peyre H. (praca zbiorowa), Tożsamość a odmienność kulturowa, Warszawa: Wydawnictwo IP PAN, s. 20.

${ }^{8}$ H. Malewska-Peyre (2000), Ciągłość i zmiana tożsamości, „Kultura i Społeczeństwo”, nr 1, s. $135-137$. 
Nasuwa się jednak kolejne pytanie: w jaki sposób tożsamość jest modyfikowana? W jaki sposób tożsamość jest przekształcana pod wpływem nowych doświadczeń? W jaki sposób jednostka pozostaje tą samą, pomimo że ciągle się zmienia? Pytania te stały się dla mnie na tyle nurtujące, że zdecydowałam się zastanowić nad tym problemem znacznie głębiej i podjąć próbę odpowiedzi.

\section{Migracja permanentna}

Na rozwój tożsamości jednostki ma wpływ zaistnienie nowego kontekstu społeczno-kulturowego ${ }^{9}$. Przykładem takiej sytuacji jest wyjazd z kraju pochodzenia i doświadczenie życia w środowisku odmiennym kulturowo. Migracje nie są zjawiskiem nowym, jednak zmieniają swój charakter, powodując, że na przebieg modyfikacji tożsamości mogą mieć wpływ inne czynniki niż w przeszłości. W związku z tym przed przystąpieniem do omówienia badań, przeprowadzonych wśród osób zmieniających swoje miejsce pobytu, przedstawię główne cechy współczesnych migracji. W tym celu odwołam się do dorobku Stephena Castlesa i Marka Millera. Zgodnie z ich przewidywaniami, obecnie mamy do czynienia z globalizacją, dyferencjacją, feminizacją oraz upolitycznieniem migracji, a także wzrostem ich liczby ${ }^{10}$.

Globalizacja migracji oznacza, że kraje dotychczas uważane za typowe kierunki emigracji i imigracji nie są jednoznacznie rozpoznawalne. Migracje są złożonym układem powiązań ${ }^{11}$, a niektóre kraje są jednocześnie krajami wysyłającymi i krajami przyjmującymi.

Wzrost liczby migracji oraz ich upolitycznienie wpływają na kształtowanie polityki międzynarodowej oraz polityki bezpieczeństwa państw, zwłaszcza w kontekście zagrożenia terroryzmem. W literaturze poświęconej temu zagadnieniu wskazuje się na problem integracji imigrantów ze społecznością nowego kraju pobytu. Podkreślić jednak należy, że obecnie w wielu miejscach powstają wielokulturowe społeczności imigranckie ${ }^{12}$, których członkowie charakteryzują się podwójną lub wieloraką identyfikacją narodową. W związku z tym państwa nie dążą już do asymilacji migrantów, ale stawiają kulturę i dziedzictwo osób przyjezdnych na równym poziomie z kulturą społeczeństwa przyjmującego. Dzięki temu imigranci

9 S. Krzychała (2007), Ryzyko własnego życia. Indywidualizacja w późnej nowoczesności, Wrocław: Wydawnictwo Naukowe Dolnośląskiej Szkoły Wyższej Edukacji TWP we Wrocławiu, s. 226.

${ }^{10}$ S. Castles, M. J. Miller (1998), The Age of Migration. International Population Movements in the Modern World, New York: Palgrave, s. 8-9.

${ }^{11}$ E. Budakowska (2005), Współczesne migracje a nowe wyzwania wobec identyfikacji narodowo-kulturowej, w: Budakowska E. (red.), Tożsamość bez granic. Wspótczesne wyzwania, Warszawa: Wydawnictwo Uniwersytetu Warszawskiego, s. 56.

${ }^{12}$ D. Niedźwiecki (2010), Migracje i tożsamość. Od teorii do analizy przypadku, Kraków: Wydawnictwo NOMOS, s. 34-35. 
mają możliwość zachowania swoich tradycji, religii, zwyczajów, a wszelkie przejawy nietolerancji są społecznie piętnowane ${ }^{13}$.

Następna cecha wiąże się z dyferencjacją migracji, czyli z faktem, że różne typy migracji zachodzą w tym samym czasie. Obecnie przemieszczają się nie tylko osoby bez kwalifikacji, które nie mogą znaleźć pracy w kraju pochodzenia, ale także wysokiej klasy profesjonaliści, dla których wyjazd za granicę jest zaplanowanym działaniem służącym realizacji ich wysokich aspiracji zawodowych. Specjaliści międzynarodowi nie pochodzą z regionów o wysokiej skali bezrobocia, nie decydują się na emigrację z powodu braku pracy lub w celu otrzymania wyższego wynagrodzenia. W ich przypadku przyczyną zmiany miejsca pobytu jest możliwość rozwoju oraz dostęp do najnowszych technologii. Osoby te z wyprzedzeniem określają swoje cele zawodowe i przyszłe miejsce pracy ${ }^{14}$. Równocześnie nie zniknęła migracja osób niewykwalifikowanych, które podróżują w celu znalezienia jakiejkolwiek pracy. Migracja zarobkowa zmieniła jednak swój charakter: pobyt w innym miejscu jest często ograniczony w czasie, a powroty do kraju pochodzenia są wielokrotne ${ }^{15}$.

Nowym zjawiskiem, wskazanym przez Castlesa i Millera jest także feminizacja migracji. Obecnie kobiety stanowią znaczącą liczbę we wszystkich typach migracji (np. migracje pracownicze kobiet, kobiet-uchodźców).

Nowe cechy migracji powodują, że pojęcie to rozumiane tradycyjnie ${ }^{16}$ - jako przemieszczanie się jednostek lub grup z jednego kraju do drugiego - jest niewystarczające. W nowym kontekście społecznym zauważam zjawisko polegające na nieustannym przemieszczaniu się jednostek do kolejnych miejsc pobytu. Moim zdaniem należy wyróżnić typ migracji przestrzennej, który będzie odnosił się do sytuacji jednostek ukierunkowanych na pozostawanie w ciągłym ruchu. Migracja ukierunkowana na osiedlenie się (migracja osiedleńcza) i migracja ukierunkowana na powrót do kraju pochodzenia (migracja czasowa) są nieadekwatne do sytuacji jednostek wielokrotnie zmieniających miejsce pobytu. W związku z tym wyróżniam szczególny typ migracji przestrzennej - migrację permanentną.

Migracja permanentna to wielokrotna, fizyczna zmiana miejsca pobytu jednostki, która nie jest ukierunkowana na osiedlenie się w nowym kraju, lecz na przemieszczanie się do kolejnych krajów. Ten typ migracji może odbywać się w różnych kierunkach, łącznie z powrotami do poprzednich miejsc pobytu i jest związany z krótszymi lub dłuższymi pobytami w różnych miejscach, oddzielonymi lub nie,

13 J. Urry (2009), Socjologia mobilności, Warszawa: Wydawnictwo Naukowe PWN, s. 239-240.

${ }^{14}$ P. Kaczmarczyk, M. Okólski (2005), Migracje specjalistów wysokiej klasy w kontekście członkostwa Polski w Unii Europejskiej, Warszawa: Urząd Komitetu Integracji Europejskiej, Departament Analiz i Strategii.

15 D. Niedźwiecki (2012), Tożsamość społeczna migrantów wahadłowych jako wyzwanie badawcze, „Studia Migracyjne - Przegląd Polonijny”, nr 4, s. 5-22.

${ }^{16}$ H. Kubiak, K. Slany (1999), Migracje, w: Bokszański, Z. et al.(red.), Encyklopedia socjologii, tom 2, Warszawa: Oficyna Naukowa, s. 243-249. 
pobytami w kraju pochodzenia. $\mathrm{W}$ przyjętej przeze mnie definicji zaznaczam, że dotyczy ona przemieszczania się w przestrzeni fizycznej (geograficznej). Problematyka migracji permanentnej jest dla mnie interesująca, jednak nie z punktu widzenia „przywiązania” do terytorium, ale przestrzeni relacji społeczno-kulturowych.

Rodzaj i rozmiar doświadczeń migrantów permanentnych jest odmienny od osób jednokrotnie przeprowadzających się do innego kraju (np. wielokrotnie przechodzą procesy adaptacyjne w kolejnych miejscach pobytu). Równocześnie pozostawanie w ciągłym ruchu wiąże się z podobnymi trudnościami związanymi z wyjazdem, jakich doświadczają także inni migranci (np. silne emocje związane z rozłąką z najbliższymi, zwłaszcza w początkowym okresie pobytu za granicą).

Migracja permanentna i tożsamość są ze sobą wzajemnie powiązane, zwłaszcza w przestrzeni społeczno-kulturowej. Zmiana miejsca pobytu i doświadczenie życia w innych kulturach, pomiędzy którymi czasami trudno znaleźć punkty wspólne, odmienny sposób postrzegania ludzi i świata, inne priorytety i aspiracje życiowe, aż wreszcie inny styl życia i rozwiązywania codziennych problemów sprawia, że jednostka potrzebuje ponownie odpowiedzieć na pytanie „kim jestem?”. Sytuacja migracji permanentnej staje się przyczyną dylematów jednostki, a mianowicie: które wartości, normy i wzory zachowań przyjąć za swoje oraz jak je połączyć z kulturą kraju pochodzenia. Zbierając doświadczenia życiowe, jednostka w sytuacji migracji permanentnej weryfikuje obraz siebie nie tylko w stosunku do ojczyzny i nowego kraju zamieszkania, jak ma to miejsce w przypadku migracji czasowej lub osiedleńczej, ale także w stosunku do wielu wcześniejszych i późniejszych miejsc swojego pobytu.

Zasygnalizowane tutaj problemy wymagały wejścia w świat empirii i przeprowadzenia badań własnych. Dzięki temu było możliwe podjęcie pogłębionej refleksji nad procesem zmian w obszarze tożsamości.

\section{Badania własne nad modyfikacją tożsamości narodowej polskich studentów}

W przeprowadzonych badaniach dążyłam do odpowiedzi na pytanie badawcze dotyczące tego, w jaki sposób tożsamość jednostki jest modyfikowana w sytuacji ciągłej zmiany pobytu. Przygotowując projekt badań, zawęziłam pojęcie tożsamości do aspektu narodowego, czerpiąc z dorobku Antoniny Kłoskowskiej ${ }^{17}$. Moją uwagę skupiłam na roli przestrzeni społeczno-kulturowej. Dla celów operacyjnych używałam określenia tożsamości narodowej rozumianej jako zbiór autodefinicji jednostki, odnoszących się do dwóch elementów: identyfikacji narodowej oraz walencji kulturowej.

17 A. Kłoskowska (1996), Kultury narodowe u korzeni, Warszawa: Wydawnictwo Naukowe PWN. 
Pierwszy element - identyfikacja narodowa - oznacza poczucie przynależności do wspólnoty narodowej. W przeprowadzonych przeze mnie badaniach przyjęłam, że identyfikacja narodowa przejawia się w relacjach z członkami wspólnoty pochodzenia w kraju i na emigracji oraz w postawach i zachowaniach wobec wspólnoty pochodzenia. Wymiar ten obejmował również sposób budowania relacji jednostki z przedstawicielami innych społeczności: z członkami społeczności aktualnego kraju pobytu / kolejnych krajów pobytu oraz z członkami innych społeczności, którzy znajdują się również w sytuacji migracji permanentnej (społeczność międzynarodowa). Uznałam, że poczucie przynależności do tych społeczności może mieć wpływ na poczucie przynależności do wspólnoty pochodzenia.

Drugi element - walencja kulturowa - oznacza przyswojenie kultury oraz uznanie jej za własną, bliską, wymagającą poczucia uczestnictwa we wspólnocie ${ }^{18}$. W przeprowadzonych badaniach przyjęłam, że wymiar walencji kulturowej jest wyrażany poprzez znajomość i stosunek do kultury (rozumianej jako wartości, wzory i normy zachowań, symbole) oraz poprzez uczestnictwo w życiu społeczno-kulturalnym: wspólnoty pochodzenia w kraju i na emigracji, społeczności aktualnego kraju pobytu oraz społeczności międzynarodowej.

Połączenie dwóch wymiarów pozwoliło ukazać związki między uczestnictwem w kulturze i relacjami z innymi a sposobem modyfikacji tożsamości (typem tożsamości).

Barierą, której byłam świadoma od początku realizacji mojego projektu, były różnice kulturowe pomiędzy badaczem a badanymi, które wpływają na przebieg oraz wyniki badań. Badacz tożsamości ma dostęp tylko do jej przejawów w zachowaniach osób badanych, w tym do ich deklaracji dotyczących charakterystyk samych siebie. W opisywaniu samego siebie ogromne znaczenie ma m.in. język, który jest zasobem kultury symbolicznej i wymaga właściwej interpretacji. Uznałam, że bez wiedzy o kulturze osób badanych będzie mi bardzo trudno zrozumieć przekaz zawarty w ich wypowiedziach. Ponadto sama tożsamość w ujęciu procesualnym jest kształtowana $\mathrm{w}$ trakcie interakcji - wysyłania, przyjmowania i interpretowania przekazów ${ }^{19}$. Interakcja przebiega jednak w pewnym kontekście kulturowym, którego odpowiednie rozumienie mogłoby okazać się niezbędne do właściwej interpretacji zebranych danych jakościowych. Uwzględniając powyższe przesłanki, zdecydowałam się prowadzić badania wśród studentów międzynarodowych pochodzących z Polski. Znajomość języka polskiego i rozumienie wszelkich niuansów kulturowych zawartych w przekazie werbalnym upewniło mnie, że będę w stanie odpowiednio analizować wypowiedzi osób biorących udział w badaniu i uniknąć błędu związanego z nieznajomością kultury kraju ich pochodzenia.

18 Ibidem, s. 128.

${ }^{19}$ D. Niedźwiecki, Tożsamość społeczna..., s. 5-6. 
Badania jakościowe przeprowadziłam, wykorzystując technikę pogłębionego wywiadu indywidualnego. Uczestnikami badań byli studenci studiów licencjackich, magisterskich i doktoranckich, którzy byli związani z uczelniami zagranicznymi, m.in. z uniwersytetem w Oksfordzie, Saint Andrews, Londynie, Reading oraz Środkowoeuropejskim Uniwersytetem w Budapeszcie. Należy podkreślić, że niektórzy z uczestników badań byli wcześniej uczniami szkół za granicą lub poprzednio studiowali na innych uniwersytetach w tym samym lub w innym kraju. Długość ciągłego pobytu za granicą (nieoddzielonego dłuższym pobytem w Polsce) uczestników badań była zróżnicowana w przedziale od dwóch do dziesięciu lat. Zróżnicowanie uczestników badań pozwoliło na uwzględnienie różnorodności ich historii życiowych, poglądów i doświadczeń oraz odmiennego podejścia do badanego zjawiska. Dzięki temu mogłam wykazać procesualność tożsamości i wyodrębnić wszystkie możliwe typy jej modyfikacji.

Uznałam, że regularni studenci międzynarodowi, przebywający w wielokulturowym środowisku i realizujący lub zamierzający realizować pobyt w wielu krajach, mogą doświadczać rozterek wokół własnej tożsamości i, prowadząc badania wśród tych osób, będę w stanie odpowiedzieć na postawione pytanie badawcze. Do grupy badawczej nie zaliczyłam studentów biorących udział jedynie w wymianach uniwersyteckich lub wyjazdach studyjnych. Wprawdzie studenci krótkoterminowi doświadczają odmienności kulturowej, ale tylko przez krótki czas i punktem odniesienia pozostaje dla nich nadal kraj pochodzenia. Uznałam, że w tej sytuacji wpływ pobytu za granicą na modyfikację ich tożsamości jest ograniczony.

Wywiady przeprowadziłam w okresie od czerwca 2012 roku do stycznia 2013 roku. Łącznie przeprowadziłam 14 wywiadów ( 3 wywiady odbyły się w Oksfordzie, $6 \mathrm{w}$ Londynie, $1 \mathrm{w}$ Monachium, $4 \mathrm{w}$ Polsce). Ze względu na styl życia studentów wywiady nie zawsze odbywały się w miastach, gdzie znajdował się uniwersytet, na którym aktualnie studiowali. Badania prowadziłam w miejscach, gdzie osoby badane przebywały i dysponowały czasem, by wziąć udział w wywiadzie. Kontakt z uczestnikami badań nawiązałam przede wszystkim poprzez stowarzyszenia studenckie, portale społecznościowe oraz za pośrednictwem kolejnych studentów, którzy już byli zaangażowani w moje badania (tzw. metoda kuli śnieżnej). Wszystkie wywiady przeprowadziłam osobiście podczas bezpośrednich spotkań z moimi rozmówcami.

Osoby w sytuacji migracji permanentnej charakteryzuje swoboda podróżowania, realizowanie własnych planów edukacyjnych i/lub zawodowych, otwartość na poznawanie innych i - przynajmniej z założenia - łatwość adaptowania się do nowych miejsc i środowisk. Studenci z własnej woli często zmieniają lub zamierzają zmieniać miejsce pobytu w celu doświadczenia życia w innym kraju, poszerzenia swojego dorobku naukowego lub uzyskania doświadczenia zawodowego. Środowisko akademickie, w którym przebywają, stanowią osoby pochodzące w różnych krajów, które również są skłonne do zmiany miejsca pobytu. 
Młodzi Polacy, którzy wyjechali z kraju w celu studiowania na zagranicznych uniwersytetach, stanowią szczególną społeczność wśród innych emigrantów. Ich wyjazd nie jest spowodowany złą sytuacją ekonomiczną, a w nowym kraju pobytu nie podejmują pracy poniżej swoich kwalifikacji ani nie korzystają z zasiłków socjalnych dla osób bezrobotnych. Ponadto posługują się bardzo dobrze językiem obcym. Wszystko to powoduje, że zaprzeczają stereotypowi Polaka - imigranta: pracownika niewykwalifikowanego, podejmującego najcięższe prace ${ }^{20}$. Osoby podejmujące zagraniczne studia są ukierunkowane na częstą zmianę miejsca pobytu w celu doświadczenia życia w innym kraju, poszerzenia swojego dorobku naukowego lub uzyskania międzynarodowego doświadczenia zawodowego. Polscy studenci równocześnie pozostają ciągle członkami wspólnoty narodowej i mimo że korzystają ze swobody przemieszczania się, jaką daje Unia Europejska, doświadczają problemów związanych $\mathrm{z}$ adaptacją społeczno-kulturową do nowych miejsc pobytu.

Osoby badane zwracały uwagę na swobodę podróżowania, brak przymusu pobytu w innym kraju i możliwość powrotu w każdej chwili do Polski. Brak negatywnych doświadczeń związanych z brakiem pracy, biedą i wojną czynią migrację doświadczeniem pozytywnym. Uczestników badań wyróżniała: świadomość konieczności wchodzenia w interakcje z mieszkańcami kraju, w którym przebywają, chęć poznania kultury kraju pobytu, otwartość na nawiązanie relacji ze społecznością międzynarodową. Trudności, z którymi spotykają się osoby badane (nie zawsze przychylna postawa członków społeczności kraju pobytu wobec przybyszów), nie zmieniają faktu, że obraz, który wyłania się z przeprowadzonych badań nie jest negatywny. Osoby badane nie pozostają odseparowane od społeczności przyjmującej oraz jednocześnie mają możliwość zachowania kultury kraju pochodzenia.

Tak jak wspomniałam powyżej, badania przeprowadziłam, wykorzystując technikę pogłębionego wywiadu indywidualnego. Scenariusz wywiadu zawierał pytania otwarte o zwartym zakresie tematycznym. Ogólne dyspozycje pozwoliły na indywidualne podejście do każdej z badanych osób. Podczas zbierania danych mogłam uszczegółowić pytania i dzięki temu dostrzec rzeczywiste problemy i obszary moich badań. Swoboda tej formy wywiadu umożliwiła dostosowanie kolejności pytań do przebiegu wywiadu oraz zadawania, w zależności od potrzeb, dodatkowych pytań. Osobom badanym taka forma wywiadu dała możliwość posługiwania się w wypowiedzi własnymi sformułowaniami, ujęcia zagadnień w subiektywnym kontekście oraz rozszerzenia lub skrócenia odpowiedzi na pytania.

Wywiady rozpoczynały się od pytań wprowadzających, mających na celu nawiązanie kontaktu z badanym. Pytania związane były z przyczynami i okolicznościami

${ }^{20}$ Badania przeprowadzone przez QRS Market Research Ltd w ramach projektu „Wizerunek Polski i Polaków w Wielkiej Brytanii", J. Fomina, J. Frelak (2011), Wizerunek Polski i Polaków w Wielkiej Brytanii. Raport z badań, Warszawa: Instytut Spraw Publicznych. 
wyjazdu, oceną tej decyzji z perspektywy czasu oraz planami na przyszłość osób badanych. Następnie kolejność poruszanych zagadnień wynikała $\mathrm{z}$ naturalnego przebiegu rozmowy. Czasami zadawałam dodatkowe pytania, które miały na celu pogłębienie wypowiedzi lub prosiłam o dodatkowe wyjaśnienie omawianych kwestii. Pytania obejmowały m.in. wyznaczniki „bycia Polakiem”, poczucia „bycia pomiędzy" krajem pochodzenia a krajem pobytu, wyrażenia opinii na temat znaczenia przynależności narodowej oraz sensu poznawania kultury społeczności kraju pobytu w sytuacji częstej zmiany miejsca zamieszkania. Podczas wywiadu zadawałam pytania dotyczące budowania i podtrzymywania relacji ze wspólnotą pochodzenia. Uczestnicy badań byli proszeni o ustalenie hierarchii swoich relacji z innymi, a mianowicie: relacji z rodzicami / rodziną / przyjaciółmi w Polsce, relacji z innymi osobami z Polski, które również przebywają za granicą, relacji z innymi studentami międzynarodowymi, relacji z członkami społeczeństwa kraju przyjmującego. Uczestnicy badań zostali poproszeni o określenie trwałości tych relacji. W scenariuszu wywiadu zostały zawarte pytania dotyczące uczestnictwa w życiu społeczno-kulturowym kraju pochodzenia i kraju pobytu (np. obchodzenie świąt, uczestnictwo $\mathrm{w}$ wyborach). Osoby badane były proszone o wyrażenie swojej opinii na temat czynnego udziału w życiu organizacji studentów międzynarodowych, w tym stowarzyszeniu polskich studentów. Podczas wywiadu uczestnikom zostało zadane, w sposób pośredni, pytanie o ich autodefinicje - w jaki sposób chcą być postrzegani przez społeczeństwo kraju pobytu - jako imigranci, jako Polacy, jako członkowie społeczeństwa kraju pobytu czy jako indywidualne jednostki? Pytanie z jednej strony zawężało zagadnienie tożsamości do dwóch badanych elementów i ukierunkowało uczestnika na zakres tematyczny badań. Z drugiej strony, dzięki otwartemu charakterowi wywiadu, uczestnicy uzupełniali pytanie o nowe określenia.

W wywiadzie uwzględniłam dwa rodzaje pytań: (1) odnoszące się wprost do samookreśleń uczestników oraz (2) zmierzające do ukazania tożsamości poprzez inne obserwowalne wskaźniki ${ }^{21}$ (np. udział w wyborach, aplikowanie o obywatelstwo kraju pobytu).Owa strategia badawcza była przyjęta w oparciu o wskazówkę Ewy Nowickiej, która twierdzi, że rozpatrując tożsamość jednostek rozumianą jako rodzaj samookreślenia, oczekuje się od badanych deklaracji (za kogo badany się uznaje) oraz poszukuje się elementów tożsamości w różnego typu wypowiedziach lub działaniach. Drugi sposób okazuje się bardzo przydatny i pokazuje złożoność tożsamości osób badanych ${ }^{22}$.

Podczas analizy pierwszych czterech wywiadów dane zostały przeze mnie posortowane według nadanych kodów. Kodowanie polegało na przypisywaniu danemu

${ }^{21}$ E. Nowicka (2007), Podwójna tożsamość. Dzieci małżeństw mieszanych, w: Borowik I., Leszczyńska K. (red.), Wokół tożsamości: teorie, wymiary, ekspresje, Kraków: Wydawnictwo NOMOS, s. 108.

${ }^{22}$ E. Nowicka (2008), Powrót do domu czy emigracja? Co się dzieje z tożsamością, w: Kempny M., Woroniecka G., Załęcki P. (red.), Tożsamość i przynależność. O współczesnych przemianach identyfikacji kulturowych w Polsce i w Europie, Toruń: Wydawnictwo Naukowe UMK, s. 26-27. 
fragmentowi tekstu jednego lub kilku słów podstawowych. Pozwoliło to, podczas analizy kolejnych danych, na identyfikację wypowiedzi zgodnie z opracowaną listą kodów $^{23}$. Następnie, poprzez porównywanie i kategoryzowanie danych, ukształtowała się struktura stanowiąca ważny krok w kierunku całościowego ujęcia zagadnienia. Ciągłe porównywanie wypowiedzi osób badanych - ich spójność lub sprzeczność, podobieństwo lub odmienność - stanowiło etap prowadzący do wysuwania twierdzeń bardziej ogólnych ${ }^{24}$. Poprzez porównywanie ze sobą różnych przypadków określiłam to, co je wzajemnie wiąże i co jest dla nich wspólne. Podczas analizy danych uwzględniłam również specyficzne przypadki, poszukując ich uzasadnienia. Podjęłam starania, aby je wyjaśnić, a tym samym uniknąć zarzutu wyboru tylko subiektywnych przypadków, które potwierdzałyby wyciągane wnioski ${ }^{25}$.

Prekonceptualizacja problemów badawczych w moim projekcie została ograniczona do minimum. Szczegółowe problemy i kategorie badawcze zostały sformułowane dopiero po zebraniu pierwszych materiałów empirycznych. Po przeprowadzeniu czterech wywiadów i ich analizie zwróciłam uwagę na nowe aspekty badanego zjawiska, których nie brałam początkowo pod uwagę, a które później uznałam za warte uwzględnienia w moim projekcie. Inne zaplanowane początkowo pytania $\mathrm{z}$ kolei okazały się nieadekwatne w stosunku do wybranej przez mnie grupy badawczej. W związku z tym podjęłam decyzję o rezygnacji z nich w dalszych badaniach. Dzięki wprowadzanym zmianom tematyka wywiadów została przeze mnie zawężona w taki sposób, aby umożliwić zebranie danych najbardziej przydatnych do opracowania typologii modyfikacji tożsamości. W związku z tym, przed przystąpieniem do zbierania kolejnych danych, scenariusz wywiadu został przeze mnie częściowo zmieniony. Dzięki temu w drugim etapie zbierania danych dążyłam do tego, aby wyróżnione w pierwszej fazie kategorie badawcze uległy „nasyceniu”. Zbieranie danych kontynuowałam tak długo, aż uznałam, że kolejne dane, zbierane podczas wywiadów, nie przynoszą nowych i znaczących informacji, lecz powtarzają się, pokazując pewne prawidłowości i są wyczerpujące. Zebrane dane podczas 14 wywiadów są bardzo bogate poznawczo, gdyż odpowiedzi osób badanych były zazwyczaj merytoryczne i bezpośrednio odnosiły się tematyki badań. Ponadto, przyjęta przeze mnie strategia badawcza - analiza przypadków - pozwoliła mi na dogłębną i wyczerpującą analizę każdego wywiadu, a w konsekwencji na osiągniecie celu badań i wyróżnienie typów modyfikacji tożsamości.

Przeciwnicy metody studium przypadków twierdzą, że nie można dokonywać uogólnień na podstawie pojedynczego przypadku i dlatego studium przypadku nie

${ }^{23}$ S. Kvale (2004), InterViews. Wprowadzenie do jakościowego wywiadu badawczego, Białystok: TransHumana, s. 195.

${ }^{24}$ U. Flick (2010), Projektowanie badania jakościowego, Warszawa: Wydawnictwo Naukowe PWN, s. 170-174.

${ }^{25}$ D. Silverman (2009), Interpretacja danych jakościowych: metody analizy rozmowy, tekstu $i$ interakcji, Warszawa: Wydawnictwo Naukowe PWN, s. 260-261. 
wnosi niczego do rozwoju naukowego. Ograniczona liczba przypadków, wybranych bez ścisłego klucza, ich zdaniem, nie daje możliwości uogólnień. Z kolei zwolennicy tej metody podkreślają jej znaczenie dla rozwoju naukowego. Bent Flyvbjerg twierdzi, że analizowane w trakcie studium przypadków heterogeniczne i nietypowe przypadki mogą dostarczyć więcej informacji niż przypadki reprezentatywne, typowe lub przeciętne i mogą odegrać ważną rolę w rozwoju teoriii ${ }^{26}$.

W moich badaniach, wpisujących się w orientację jakościową, pojęcia reprezentatywności nie można rozumieć w ten sam sposób jak w badaniach statystycznych. Kategorię reprezentatywności zastąpiłam kategorią typowości. Opracowanej przeze mnie typologii nie należy zatem traktować jako generalizacji, rozciągającej się na całą populację osób doświadczających częstej zmiany pobytu. Wskazane przeze mnie typy tożsamości nie oznaczają standaryzacji, ale jedynie porządkują poszczególne przypadki. Ponadto zastosowana metoda analizy przypadków nie usiłuje kontrolować wszystkich uzyskanych podczas wywiadów informacji. Generalizacja uzyskanych wyników jest ograniczona warunkami badania i nie są możliwe wnioski co do częstotliwości występowania przedstawionych typów ${ }^{27}$.

Celem typologii modyfikacji tożsamości w sytuacji permanentnej migracji jest wskazanie wariantów takiej zmiany. W związku z tym dążyłam do wskazania wszystkich możliwych typów tożsamości. Pogłębiona analiza każdego przypadku pozwoliła na zwrócenie uwagi na problemy, które mogłyby pozostać niedostrzeżone w sytuacji badań na dużej próbie badawczej i wyborze przypadków reprezentatywnych.

Przeprowadzenie 14 wywiadów pozwoliło mi przyjąć podejście indywidualne do każdego z przypadków. Każda z osób badanych stanowi niepowtarzalną jednostkę, a przebieg migracji i towarzyszące jej okoliczności są odmienne dla każdej $z$ badanych osób. Należy zaznaczyć, że opracowana przeze mnie koncepcja typów tożsamości ma charakter porządkujący, a „idealne” typy każdej z wyróżnionych tożsamości nie zdarzają się faktycznie w rzeczywistości społecznej. Każdy uczestnik badań jest indywidualną jednostką i jego tożsamość jest wyjątkowa i niepowtarzalna, wykraczająca poza określony typ.

\section{Typologia modyfikacji tożsamości narodowej}

W wyniku szczegółowego studium analizy przypadków opracowałam typologię modyfikacji tożsamości narodowej jednostki znajdującej się w sytuacji migracji permanentnej. Wyróżniłam pięć typów modyfikacji tożsamości, a mianowicie:

${ }^{26}$ B. Flyvbjerg (2005), Pięć mitów o badaniach typu studium przypadku, „Studia Socjologiczne", nr 2, s. 41-69.

27 A. Kłoskowska, Kultury narodowe u korzeni..., s. 129-130. 
„ja” Polak - obywatel świata; „ja” obywatel świata urodzony w Polsce; „ja” Polak, obywatel obecnego kraju pobytu i obywatel świata; ,ja" Polak i obywatel obecnego kraju pobytu; ,ja” obywatel świata i/lub obywatel obecnego kraju pobytu.

\section{- Typ 1: „ja” Polak - obywatel świata}

Jednostka definiuje siebie jako Polaka, który jest równocześnie obywatelem świata / Europejczykiem. Tożsamość jednostki jest budowana w oparciu o silne poczucie przynależności do kraju pochodzenia i uznanie kultury narodowej za własną. Na fundamencie identyfikacji narodowej i uznania kultury narodowej za własną jednostka buduje swoją przynależność do społeczności międzynarodowej i uznanie jej kultury za własną. W tym typie tożsamości jednostka nie definiuje siebie w odniesieniu do kraju aktualnego miejsca pobytu, gdyż nie ma poczucia przynależności do jego społeczności i nie uznaje jej kultury za własną.

\section{- Typ 2: „ja” obywatel świata, urodzony w Polsce}

Jednostka definiuje siebie jak obywatela świata, który urodził się „akurat” w Polsce, a mógłby urodzić się w innym kraju. Tożsamość jednostki jest budowana w oparciu o silne poczucie przynależności do społeczności międzynarodowej i uznanie tej kultury za własną. Jednostka definiuje siebie w odniesieniu do kraju pochodzenia, który postrzega jako miejsce urodzenia, wychowania, otrzymania edukacji. W tym typie tożsamości jednostka nie definiuje siebie w odniesieniu do kraju aktualnego miejsca pobytu, gdyż nie ma poczucia przynależności do jego społeczności i nie uznaje jej kultury za własną.

\section{- Typ 3: „ja” Polak, obywatel obecnego kraju pobytu i obywatel świata}

Jednostka definiuje siebie jako Polaka, który ciągle zmienia miejsce zamieszkania, jednak gdziekolwiek przebywa, jest „dobrym obywatelem” kraju pobytu, będąc zaangażowanym w lokalne sprawy, aktywnie uczestnicząc w życiu społeczno-kulturalnym, nawiązując relacje z członkami społeczności kraju pobytu.

Tożsamość jednostki jest budowana w oparciu o silne poczucie przynależności do kraju pochodzenia i uznanie kultury narodowej za własną. Na tym fundamencie jednostka buduje swoją przynależność do obecnego kraju pobytu i do społeczności międzynarodowej. W tym typie tożsamości jednostka uznaje kulturę społeczności międzynarodowej za własną oraz kulturę kraju pobytu za bliską.

\section{- Typ 4: „ja” Polak i obywatel obecnego kraju pobytu}

Jednostka definiuje siebie jako Polaka oraz obywatela obecnego kraju pobytu. Tożsamość jednostki jest budowana w oparciu o silne poczucie przynależności do kraju pochodzenia i uznanie kultury narodowej za własną. Na tym fundamencie jednostka buduje swoją przynależność do obecnego kraju pobytu, będąc zaangażowaną w lokalne sprawy, aktywnie uczestnicząc w życiu społeczno- 
-kulturalnym, nawiązując relacje z członkami społeczności kraju pobytu. W tym typie tożsamości jednostka nie definiuje siebie w odniesieniu do społeczności międzynarodowej.

\section{- Typ 5: „ja” obywatel świata i/lub obywatel obecnego kraju pobytu ${ }^{28}$}

Jednostka definiuje siebie jako obywatela świata, który równocześnie jest obywatelem obecnego kraju pobytu. Jednostka ma poczucie przynależności do społeczności międzynarodowej i kulturę tej społeczności uznaje za własną oraz ma poczucie przynależności do społeczności kraju pobytu i jej kulturę uznaje za własną. Tożsamość jednostki jest budowana w oparciu o odrzucenie poczucia przynależności narodowej do kraju pochodzenia i nieuznawanie kultury narodowej za własną.

Osoby uczestniczące w badaniach, wyjeżdżając z kraju pochodzenia, traktowały swój wyjazd jako przygodę, wyzwanie lub ryzyko, które zakończą się, dla większości z nich, prawdopodobnie wraz z uzyskaniem dyplomu studiów na uniwersytecie. Pobyt w innym kraju spowodował jednak, że niektórzy uczestnicy zaczęli postrzegać siebie jako osoby mobilne, które komfortowo czują się w środowisku międzynarodowym i mają wysokie aspiracje edukacyjno-zawodowe (wyjątkiem jest jeden przypadek). Ich tożsamość narodowa, rozumiana jako zbiór autodefinicji jednostki, odnoszących się do dwóch elementów, tj. identyfikacji narodowej oraz walencji kulturowej, została zmodyfikowana poprzez rozszerzenie przez osoby badane przyjmowanych wobec siebie nowych określeń (np. osoba mobilna, obywatel świata).

Dla moich rozmówców autodefinicje związane z przynależnością narodową pozostają takie same, mimo że zmieniły miejsce $\mathrm{w}$ hierarchii definicji i uległy wzmocnieniu lub osłabieniu, lecz nie zostały całkowicie odrzucone lub zamienione na inne. Identyfikacja narodowa w sytuacji migracji permanentnej, pozostając dotychczas w stanie utajenia, została uświadomiona i w przypadku niektórych osób zaczęła być wyraźnie manifestowana lub, wręcz przeciwnie, ukrywana. Analogiczne zjawisko następuje w przypadku przyswojenia kultury kraju pochodzenia, kraju aktualnego miejsca pobytu i społeczności międzynarodowej. Znajomość kultur nie zawsze oznacza przyjęcie ich za własne, a poszczególne kultury nie zajmują takiego samego miejsca w strukturze walencji.

Modyfikacja tożsamości narodowej łączy się także ze zmianą rozumienia identyfikacji narodowej i zmianą sposobu jej wyrażania. Wyjazd za granicę uświadamia osobom badanym znaczący wpływ socjalizacji w kraju pochodzenia. W związ$\mathrm{ku} \mathrm{z}$ tym rozmówcy precyzują autodefinicje związane z identyfikacją narodową i uznaniem kultury narodowej za własną. Osoby badane, pomimo wykształcenia

${ }^{28}$ Żaden z uczestników badań nie reprezentował tego typu. Niektóre osoby biorące udział w wywiadzie jedynie wspomniały o swoich znajomych, których można przypisać do tego typu. 
i doświadczenia międzynarodowego, nie podejmują się zadania bycia liderem wśród innych grup emigrantów i nie poczuwają się do odpowiedzialności za pomoc w ich adaptacji do nowych warunków życia w kraju pobytu. Ponadto, identyfikacja narodowa nie łączy się z przywiązaniem do ziemi (terytorium) kraju pochodzenia i w ten sposób nie stoi w sprzeczności z planami dalszej migracji oraz życiem w innym kraju / w innych krajach.

Zasadniczą definicją w tożsamości osób badanych jest postrzeganie siebie jako indywidualnej jednostki. Rozmówcy zazwyczaj wyrażali swoją tożsamość poprzez przyjmowanie określenia „bycia sobą” lub poprzez swoje imię, podkreślając w ten sposób swoją indywidualność. Cel, który postawiło przed sobą wiele osób badanych, koncentruje się przede wszystkim wokół międzynarodowej kariery, samorozwoju i kontynuowania podróży. Ich plany są określane indywidualnie. Osoby uczestniczące w badaniu są ukierunkowane na realizację własnych dążeń i aspiracji związanych z karierą edukacyjno-zawodową. Używając kolejnych definicji, określają siebie poprzez pryzmat identyfikacji ze społecznością międzynarodową, wspólnotą narodową, społecznością lokalną, społecznością uniwersytetu itd. Hierarchia tych identyfikacji jest odmienna dla poszczególnych osób badanych. Uczestnictwo w narodowej wspólnocie nie wyczerpuje jednak całej tożsamości jednostki, dlatego podczas wywiadów pojawiły się także inne identyfikacje, np. związane z grupą zawodową, płcią, orientacją seksualną. Identyfikacja narodowa nie jest dla nich ani jedyną, ani najważniejszą. Występuje obok innych, równie ważnych lub nawet ważniejszych identyfikacji, zwłaszcza tych ze społecznością zawodową oraz ze społecznością międzynarodowych studentów. Warto zauważyć, że na przykład poczucie przynależności narodowej nie stało w opozycji do identyfikacji ze społecznością zawodową i dlatego mogła być ona nadal podtrzymywana. Ponadto osoby badane uważały, że dzięki własnej przynależności do prestiżowej grupy zawodowej mogą zmieniać negatywne opinie o kraju pochodzenia. W ten sposób identyfikacja zawodowa przyczyniała się do wzmocnienia ich przynależności narodowej oraz stawała się narzędziem do promowania kraju pochodzenia.

Osoby badane, pomimo że postrzegają siebie jako niepowtarzalne jednostki $\mathrm{z}$ indywidualnymi, niezależnymi od wspólnoty pochodzenia lub innych społeczności, cechami i planami, nie tworzą swojej tożsamości od początku. Z przeprowadzonych przeze mnie wywiadów wynika, że tożsamość jest modyfikowana, czyli jednostki uzupełniają swój obraz o nowe definicje.

Tożsamość jest konstruowana w trakcie trwania interakcji i poprzez relacje z innymi. Nowe doświadczenia i konieczność adaptacji do otoczenia społecznego powodują, że autodefinicje ulegają zmianie. Interakcje przebiegają nieustannie, a zatem obraz siebie jest ciągle kształtowany i nigdy nie osiąga ostatecznej formy. Tożsamość równocześnie charakteryzuje się ciągłością, która jest wyrażana poprzez odwoływanie się przez jednostkę do własnych, unikalnych doświadczeń, co umożliwia zachowanie identyczności z sobą samym z przeszłości. 
Piąty typ tożsamości - „ja” obywatel świata i/lub obywatel obecnego kraju pobytu - sugeruje przerwanie ciągłości (brak odwoływania się przez jednostkę do własnych, unikalnych doświadczeń) i identyczności z sobą samym z przeszłości. Ten typ nie był reprezentowany przez żadnego z uczestników badań. Niektóre osoby biorące udział w wywiadzie jedynie wspomniały o swoich znajomych, których tożsamość jest bliska typowi „ja” - obywatel świata i/lub obywatel obecnego kraju pobytu. W badaniach przyjęłam jednak, że tożsamość i jej modyfikacja jest procesem, a w związku z tym nie można stwierdzić, czy jednostki reprezentujące obecnie typ „ja” - obywatel świata i/lub obywatel obecnego kraju pobytu nie zmienią po raz kolejny swoich autodefinicji i nie odkryją na nowo związków ze wspólnotą i kulturą kraju swojego pochodzenia. Nie można zatem jednoznacznie stwierdzić, że przedstawiony typ oznacza przerwanie ciągłości tożsamości, gdyż byłoby to zbyt daleko posuniętym wnioskiem.

\section{Zakończenie}

Modyfikacja tożsamości odbywa się z udziałem społeczeństwa. Jednostka dostosowuje swoje zachowania do wzorów i norm kulturowych oraz przyjmuje cenione wartości. Jednostka i otoczenie społeczne wzajemnie na siebie oddziałują ${ }^{29}$. Z jednej strony jednostka jako członek wspólnot i społeczności staje się im podobna, ale z drugiej strony uformowana struktura „ja” daje poczucie wyjątkowości własnej osoby i pozwala zachować świadomość swojej podmiotowej odrębności. Stwierdzenie swojej odrębności od innych i postrzeganie siebie jako indywidualnej jednostki pozwala na rozwinięcie tożsamości oraz zachowanie ciągłości i identyczności z sobą samym w czasie. Dążenie do bycia indywidualną jednostką nie jest sprzeczne z poczuciem przynależności do wspólnoty narodowej, ponieważ identyfikacja narodowa nie wiąże się z ograniczeniami oraz koniecznością zakończenia migracji lub brania odpowiedzialności za innych członków wspólnoty narodowej. Poczucie przynależności do wspólnoty narodowej zapewnia szereg profitów, a mianowicie: bezpieczeństwo, trwałe i głębokie relacje społeczne (mimo że łączy się to $\mathrm{z}$ wysiłkiem podtrzymywania tych relacji), znany, uporządkowany i przewidywalny świat kultury narodowej (co łączy się z wysiłkiem uczestnictwa w kulturze). Poczucie indywidualizmu przejawia się w zaznaczaniu swoich osiągnięć edukacyjnych (czasami bez pomocy materialnej z kraju pochodzenia), własnych planów i działań, jednostkowego stylu życia. Silne poczucie własnej odrębności pozwala zahamować proces dewaloryzacji własnej tożsamości związanej z poczuciem przynależności narodowej i otrzymywaniem przez nowe otoczenie społeczne negatywnych przekazów na temat własnej wspólnoty pochodzenia. Konflikt wynikający z trudności

\footnotetext{
${ }^{29}$ N. Elias (2008), Społeczeństwo jednostek, Warszawa: Wydawnictwo Naukowe PWN.
} 
zachowania spójności tożsamości zostaje rozwiązany poprzez wzmocnienie tożsamości osobistej i zaznaczanie swojej odrębności jako niepowtarzalnej jednostki.

Wyróżnione typy modyfikacji tożsamości, z wyjątkiem, jak wspomniałam powyżej, typu piątego (,ja” obywatel świata i/lub obywatel obecnego kraju pobytu), wskazują, że zmiana w autodefinicjach jednostek nie dokonuje się poprzez zaprzeczenie lub odrzucenie samookreśleń odnoszących się do wspólnoty i kultury kraju swojego pochodzenia. Modyfikacja tożsamości polega na rozbudowaniu definicji, postrzegania siebie o identyfikację i walencję kulturową z nowymi krajami pobytu oraz społecznością międzynarodową i jej kulturą. Modyfikacja tożsamości nie oznacza odrzucenia przeszłości biograficznej odnoszącej się do związków ze wspólnotą i kulturą kraju pochodzenia. W przypadku typów 1-4 tożsamość zachowuje ciągłość. Tożsamość pozwala pozostać jednostce tą samą, pomimo zmian w życiu i otoczeniu wynikających $\mathrm{z}$ sytuacji migracji permanentnej. Moim zdaniem, procesu modyfikacji nie można uznać za zakończony, bowiem wraz z nowymi doświadczeniami kulturowymi i interakcjami tożsamość jednostki ciągle ewoluuje. Zaprezentowaną typologię należy zatem postrzegać dynamicznie, a nie statycznie. Poszczególnych typów nie należy jednak postrzegać jako kolejnych stadiów modyfikacji. Tożsamość narodowa w sytuacji migracji permanentnej rozwija się, nie mając ostatecznego celu, a zatem zaproponowane wymiary mogą układać się w dowolny sposób. Osoby przypisane do poszczególnych typów mogą z czasem zmienić swoje samookreślenie i zająć inne miejsce w przedstawionej typologii.

W literaturze wskazuje się na fakt, że analiza jakościowa pozwala na dogłębne, wielowymiarowe zbadanie danego problemu, ale jednocześnie jest „niedomknięta”. Analiza jakościowa otwiera następne obszary badawcze, które mogą okazać się równie ważne i ciekawe dla rozwoju nauki ${ }^{30}$. W ten sposób postrzegam opracowaną przeze mnie typologię modyfikacji tożsamości narodowej jednostki w sytuacji migracji permanentnej. Jestem przekonana, że przedstawione wyniki badań oraz wynikające $\mathrm{z}$ nich wnioski będą inspiracją do stawiania kolejnych pytań wraz z poszukiwaniem nowych obszarów badawczych.

\section{Bibliografia}

Bokszański Z. (2002), Tożsamość, w: Bokszański Z. et al. (red.), Encyklopedia socjologii, tom 4, Warszawa: Oficyna Naukowa, s. 252-255.

Bokszański Z.(2005), Tożsamości zbiorowe, Warszawa: Wydawnictwo Naukowe PWN.

Budakowska E. (2005), Współczesne migracje a nowe wyzwania wobec identyfikacji narodowo-kulturowej, w: Budakowska E. (red.), Tożsamość bez granic. Współczesne wyzwania, Warszawa: Wydawnictwo Uniwersytetu Warszawskiego, s. 49-72.

${ }^{30}$ K. Kaźmierska (2008), Biografia i pamięć na przykładzie pokoleniowego doświadczenia ocalonych z zagłady, Kraków: Wydawnictwo NOMOS, s. 393. 
Castles S., Miller M. J. (1998), The Age of Migration. International Population Movements in the Modern World, New York: Palgrave.

Elias N. (2008), Społeczeństwo jednostek, Warszawa: Wydawnictwo Naukowe PWN.

Erikson E. H. (2004), Tożsamość a cykl życia, Poznań: Zysk i S-ka.

Flick U. (2010), Projektowanie badania jakościowego, Warszawa: Wydawnictwo Naukowe PWN. Flyvbjerg B. (2005), Pięć mitów o badaniach typu studium przypadku, „Studia Socjologiczne”, nr 2, s. 41-69.

Fomina J., Frelak J. (2011), Wizerunek Polski i Polaków w Wielkiej Brytanii. Raport z badań, Warszawa: Instytut Spraw Publicznych.

Kaczmarczyk P., Okólski M. (2005), Migracje specjalistów wysokiej klasy w kontekście członkostwa Polski w Unii Europejskiej, Warszawa: Urząd Komitetu Integracji Europejskiej, Departament Analiz i Strategii.

Kaźmierska K. (2008), Biografia i pamięć na przykładzie pokoleniowego doświadczenia ocalonych $z$ zagłady, Kraków: Wydawnictwo NOMOS.

Kłoskowska A. (1996), Kultury narodowe u korzeni, Warszawa: Wydawnictwo Naukowe PWN.

Krzychała S. (2007), Ryzyko własnego życia. Indywidualizacja w późnej nowoczesności, Wrocław: Wydawnictwo Naukowe Dolnośląskiej Szkoły Wyższej Edukacji TWP we Wrocławiu.

Kubiak H., Slany K. (1999), Migracje, w: Bokszański Z. et al. (red.), Encyklopedia socjologii, tom 2, Warszawa: Oficyna Naukowa, s. 243-249.

Kvale S. (2004), InterViews. Wprowadzenie do jakościowego wywiadu badawczego, Białystok: TransHumana.

Malewska-Peyre H. (1992), Ja wśród swoich i obcych, w: Boski P., Jarymowicz M., Malewska-Peyre H., Tożsamość a odmienność kulturowa, Warszawa: Wydawnictwo IP PAN, s. 17-66.

Malewska-Peyre H. (2000), Ciągłość i zmiana tożsamości, „Kultura i Społeczeństwo”, nr 1, s. $129-144$.

Mead G. H. (1975), Umyst, osobowość i społeczeństwo, Warszawa: Państwowe Wydawnictwo Naukowe.

Niedźwiecki D. (2010), Migracje i tożsamość. Od teorii do analizy przypadku, Kraków: Wydawnictwo NOMOS.

Niedźwiecki D. (2012), Tożsamość społeczna migrantów wahadłowych jako wyzwanie badawcze, „Studia Migracyjne - Przegląd Polonijny”, nr 4, s. 5-22.

Nowicka E. (2007), Podwójna tożsamość. Dzieci małżeństw mieszanych, w: Borowik I., Leszczyńska K. (red.), Wokót tożsamości: teorie, wymiary, ekspresje, Kraków: Wydawnictwo NOMOS, s. 104-119.

Nowicka E. (2008), Powrót do domu czy emigracja? Co się dzieje z tożsamością?, w: Kempny M., Woroniecka G., Załęcki P. (red.), Tożsamość i przynależność. O współczesnych przemianach identyfikacji kulturowych $w$ Polsce $i$ w Europie, Toruń: Wydawnictwo Naukowe UMK, s. 17-39.

Silverman D. (2009), Interpretacja danych jakościowych: metody analizy rozmowy, tekstu i interakcji, Warszawa: Wydawnictwo Naukowe PWN.

Urry J. (2009), Socjologia mobilności, Warszawa: Wydawnictwo Naukowe PWN. 